\title{
Erdốlátogatási szokások felmérése és a fizikai aktivitás vizsgálata az Észak-Magyarország régió 55 év feletti lakosságának körében
}

\section{The study regarding forest visit habit and physical activity status for the population over 55 years in the North Hungarian Region}

\begin{abstract}
$=$
Összefoglaló: Hazánk természeti adottságai potenciális lehetőségnek tekinthetők az egészségvédelem és az egészségi állapot javításának vonatkozásában. Az erdő́k közjóléti rendeltetésének hasznos befektetésével támogathatják idősödő társadalmunkban a középés időskorúak öregedési folyamatának lassítását. A kutatási internetes, önkitöltős, validált kérdőívet az International Physical Activity Questionnaire kérdései és módszerei alapján állítottuk össze, melyben szerepeltek saját kérdések is. Az eredmények alapján elmondható, hogy a minta legnagyobb részét az Észak-Magyaroszág régió nyugdíjasklubjainak tagjai töltötték ki ( $n=103$ fö; $M=65,05)$. Az adatfeldolgozást Excel és SPSS 20.0 program segítségével végeztük. Összefoglalásként elmondható, hogy a tudományos megközelítések alátámasztják azt a tényt, hogy a testmozgás jelentős preventív hatással bír. Az erdő kínálta rekreációs lehetőségek - mint a túrázás, a kerékpározás vagy a futás - kiváló eszközként jól beilleszthetőek az idősödő korosztály életmódjába, és támogathatják, hogy a nyugdijasok is fizikailag aktív tagjai maradhassanak a társadalomnak. Kulcsszavak: erdőlátogatási szokások, fizikai aktivitás, 55 év feletti lakosság, International Physical Activity Questionnaire, Észak-Magyarország régió
\end{abstract}

Abstract: The touristic habit in the forests of the North Hungarian Region may give a good and healthy turistical programmes for the population over 55 years. The green forest may give a remarkable possibility to slow the elderly people's typical progressive disease status. The sample was sampled from some North Hungarian Retired People's clubs ( $n=103 ; M=65.0$ ). Result was measured by the basis of a validated, International Physical Activity Questionnaire. Data were analysed by Excel and SPSS.20.0 programmes. Conclusion is, that the trip in the green forest, like a hiking or cycling have a positive effect on the elderlies' health and physical activity status. Key words: touristic habits in the forest, physical activity, population over 55 years, International Physical Activity Questionnaire, North Hungarian Region

\section{A TÉMA AKTUALITÁSA}

Napjainkban a természet jelentősége mindinkább felértékelődik, egyre nagyobb a természetes életmódra törekvés igénye, így a szabadban gyakorolt sportolás felé is fokozódó igény mutatkozik (Seregi, Balogh és Lelovics, 2012). Ezt bizonyítja, hogy felgyorsult társadalmunk egyre növekvő érdeklődéssel fordul az erdő adta szolgáltatások, így a rekreációs lehetőségek irányába is. Az erdei termékek és szolgáltatások szektor magába foglalja a rekreációs szolgáltatások - mint a kirándulás vagy az élménytúra - végtelen lehetőségeit (Seregi, Balogh és Lelovics, 2012; Hegedűs, 2007). Seregi és munkatársai (2014) megfogalmazásában az erdőt úgy tekinthetjük, mint hazánk nagy kiterjedésủ, térítésmentesen igénybe vehető „tornatermét”. Az erdőről, az erdő védelméről és az erdőgazdálkodásról szóló 2009. évi XXXVII. törvény értelmében az erdő elsődleges rendeltetése védelmi, közjóléti, valamint gazdasági lehet. Lényeges, hogy a közjóléti rendeltetés külön említve van, ezzel is hangsúlyozva erdőink egészségügyi-gyógyászati, közjóléti szerepének jelentőségét (Seregi és mtsai, 2014; Magyar Közlöny, 2009). A közjólét fogalma alatt azokat az állami erdőgazdaság által végzett tevékenységeket értjük, amelyek hatnak az egyén egészségére, szellemi fejlödésére, valamint a környezettudatosságára, identitására, továbbá hatnak az egyén természetszeretetére is (Seregi, Balogh és Lelovics, 2012; Seregi és mtsai, 2014; Seregi, 2012).

\section{HOVA INKÁBB? VISSZA \\ A TERMÉSZETBE!}

Hazánk területi adottsága potenciális lehetőség a fogyasztói társadalom megváltozott igényeihez. Magyarország területének közel egyötöd részét, csaknem kétmillió hektárt borít erdő, amelynek több mint a fele van állami tulajdonban (Seregi és mtsai, 2014; Miniszteri tájékoztató, 2017; NÉBIH, 2017). Az erdők értéke felbecsülhetetlen, a statisztikailag mérhető nyereségek mellett meg kell említeni az egészségnyereséghez füződő kapcsolatát. Nagy fokú szerepe van az ember testi, lelki egészségének pozitív befolyásolásában, hangsúlyos továbbá a rekreációs-gyógyászati célokra való használhatósága is (Seregi, Lelovics és Balogh, 2012). A természetben, kiváltképp az erdőben végzett testmozgás esetében nem csupán outdoor tevékenységről beszélhetünk, miután a jobb életminőség elérését támogatja a sokszínű környezet, a természetes napfény, a levegö tisztasága (Seregi és mtsai, 2014).

\section{IDŐSEN IS?}

A rendszeres fizikai aktivitás jótékony hatásait megannyi kutatás bizonyítja, amely kedvező hatások mindenki számára érvényesülnek nemtől, kortól függetlenül (Bajsz, Császárné és Sió, 2014). Az orvostudomány bizonyította, hogy a mozgás, a rendszeres fizikai aktivitás az öregedés folyamatát lassíthatja, hozzájárul az egészséges idősödéshez és egyben egy jobb globális életminőség eléréséhez. Az idősödő és idős korosztály tekintetében a fizikai aktivitás pozitív hatású mind a mortalitás, mind pedig az összesített morbiditás csökkentése céljából (Tóth, 2017).

\section{A KUTATÁS CÉLJA}

A tanulmány egy kevésbé kutatott területre - az 55 év felettiek fizikai aktivitására és körükben hazánk erdőinek látogatottságára - fókuszál. A természetjárásra növekvő igény mutatkozik, azonban nem állnak rendelkezésre pontos adatok az erdők látogatottságát illetően (Seregi és mtsai, 2014), különösen korosztályokra lebontva. A tanulmány célja, hogy a megkérdezettek szubjektív válaszaiból és a validált International Physical Activity Questionnaire (IPAQ) kérdöív adataiból képet kapjunk az Észak-Magyarországon élő 55 év felettiek, az idősödő és idős, esetleg nagyon idős korosztályt képviselők egészségtudatos magatartásáról a fizikai aktivitás és az erdőlátogatás tükrében. 


\section{A KUTATÁS MÓDSZERTANA}

Ebben a tanulmányban az 55 év feletti korosztály került megszólításra, a kiértékelendő mintacsoport 103 főből állt. A mintán belül korcsoportok kialakítása történt, amelyben a WHO életkor szerinti felosztása volt az irányadó. A 60-74 év közötti válaszadók tartoztak az idősödők, a 75-89 év közöttiek az idősek csoportjába, a 90 évesek és az afölöttiek pedig a nagyon idősek csoportját képviselték (Olvasztóné és mtsai, 2011). Az 55-59 év közötti korcsoport megkeresésének a lényege az volt, hogy az idősödés előtti 5 éves időszak fizikai aktivitása és erdőlátogatási szokása is megmutatkozzon - mint lehetséges prevenciós eszköz -, amely részt vehet az öregedés folyamatának lassításában. A minta $80,6 \%$-a volt nő, 19,4\%-a pedig férfi. Az átlagéletkor 65,05 év, a mintába kerülés feltétele a betöltött 55 év volt, a legidősebb kitöltő 90 éves volt. A kérdőívet kitöltők többségében felsőfokú végzettséggel (42,72\%) és érettségivel (36,89\%) rendelkeztek. A válaszadók közel 14,56\%-a szakiskolát és 5,83\%-a általános iskolát végzett. A kitöltők gazdasági aktivitását tekintve nagy százalékuk (64,08\%) inaktív - nyugdíjas -, a minta többi tagja a munkaerőpiacon lát el valamilyen szellemi, fizikai vagy szellemi és fizikai munkát egyaránt.

A kvantitatív empirikus kutatás kérdőíves adatgyüjtés segítségével valósult meg. Lényeges, hogy a válaszadók maguk adták meg a fizikai aktivitásukra vonatkozó adatokat. A tanulmányba a fizikai aktivitás mérésére alkalmas IPAQ (Nemzetközi Fizikai Aktivitás Kérdőív) rövid változata került felvételre (Bajsz, Császárné és Sió, 2014; Ács és mtsai, 2018), valamint a kérdőív az erdők látogatottságára irányuló általunk összeállított kérdéseket is tartalmazott. A kutatás a Helsinki Nyilatkozat etikai elvei mentén zajlott (WHO, 2001; WMA, 2008). A statisztikai adatok elemzése során a leíró statisztika mellett összefüggés-vizsgálatok is történtek Excel és SPSS 20.0 számítógépes programokkal.

\section{A FIZIKAI AKTIVITÁS MÉRÉSE}

Az IPAQ kérdőív - mint megbízható módszer - segítségével mind a fizikai aktivitás mértéke, mind pedig a fizikai aktivitás minősége is monitorozásra került a megkérdezettek körében. Feltérképezhetővé vált a megkérdezett egyének elmúlt 7 napjára vonatkozóan a nehéz fizikai tevékenységgel, a mérsékelt erősségü testmozgással, valamint a gyaloglással eltöltött idők tartama. A különböző mértékű fizikai aktivitásokhoz (ásás, könnyű terhek cipelése, utcai gyalogos közlekedés) meghatározott metabolikus ekvivalens (MET) értékek kapcsolódnak. Az adatok elemzése során három kategória volt elkülöníthetö. A csekély aktivitás vagy teljes inaktivitás kategóriába tartozók aktivitása a $600 \mathrm{MET} /$ hét értéket nem érte el. Minimális aktivitást a 3 vagy több napon át legalább 20 percig tartó nehéz fizikai munkával; továbbá 5 vagy több napon át legalább 30 percen keresztül végzett mérsékelt erősségü fizikai aktivitással vagy gyaloglással; vagy 5 vagy több napon keresztül végzett valamilyen testmozgással lehetett elérni, aminek legalább $600 \mathrm{MET} /$ hét volt az értéke. Egészségjavító fizikai aktivitásnak számított a legalább 3 napon keresztül végzett nehéz/élénk fizikai munka végzése összesen legalább 1500 MET/hét értékben, vagy ha 7 napon keresztül különféle test- mozgások kombinációjának értéke összesen legalább a 3000 $\mathrm{MET} /$ hét értéket elérte. A kérdöív kitért továbbá az elmúlt héten üléssel töltött órák számára is (Bajsz, Császárné és Sió, 2014; Ács és mtsai, 2018).

\section{EREDMÉNYEK}

A tanulmányban az IPAQ kérdőív rövidített változatával kapott adatok alapján a vizsgált 55 év fölötti korosztályt három csoportba lehetett sorolni a fizikai aktivitásuk mentén. A válaszadók 16,5\%-ára csekély aktivitás vagy teljes inaktivitás volt jellemző. Mérsékelt erősségü fizikai aktivitást a minta 31,07\%-a mutatott, míg egészségjavító fizikai aktivitás a megkérdezettek több mint felére $(52,43 \%)$ volt jellemző. Lényeges, hogy a vizsgált csoport $17,48 \%$-a naponta több mint 5 órát töltött ülve, a mintában átlagosan közel 3 órát töltöttek üléssel naponta.

Az 55-59 év közötti korosztály fizikai aktivitását tekintve átlagosan 8563,48 MET/hét volt, míg 60-74 év közötti idősödő korosztály fizikai aktivitása átlagosan 4819,27 MET/ hét volt. Az idős korosztály összesített MET értékét tekintve, esetükben átlagosan a 2653,1 MET/hét volt jellemző. Az 1 fö 90 éves válaszadó inaktívnak tekinthető (1. ábra).

Az 55-59 éves korosztályban nem volt inaktív válaszadó, esetükben csekély aktivitást 1 fó mutatott. Ebben a csoportban többeknek $20000 \mathrm{MET} /$ hét fölötti volt a fizikai aktivitása, aminek magyarázata, hogy sokuknak még munkaviszonya van, és többen jelölték közülük, hogy fizikai munkát is végeznek. A vizsgálatban részt vettek életkora és a MET/hét értékeik között biztos, de gyenge összefüggés mutatkozott $(\mathrm{r}=-0,25)$.

Az idősödő korosztálynak a 8,96\%-a inaktívnak számított, és ugyanennyien csekély fizikai aktivitást mutattak. Ez az arány a csoportba tartozók csaknem egyötöd részét (17,92\%) teszi ki, ami tekintettel a korukra, igen magas aránynak számít. Az idősek csoportjába tartozók csaknem felére (40\%) a csekély aktivitás volt a jellemző. Az életkor és fizikai aktivitás között biztos, de gyenge kapcsolat volt tapasztalható $(r=-0,2)$.

\section{1. ábra: Fizikai aktivitás mértéke korosztályokra lebontva}

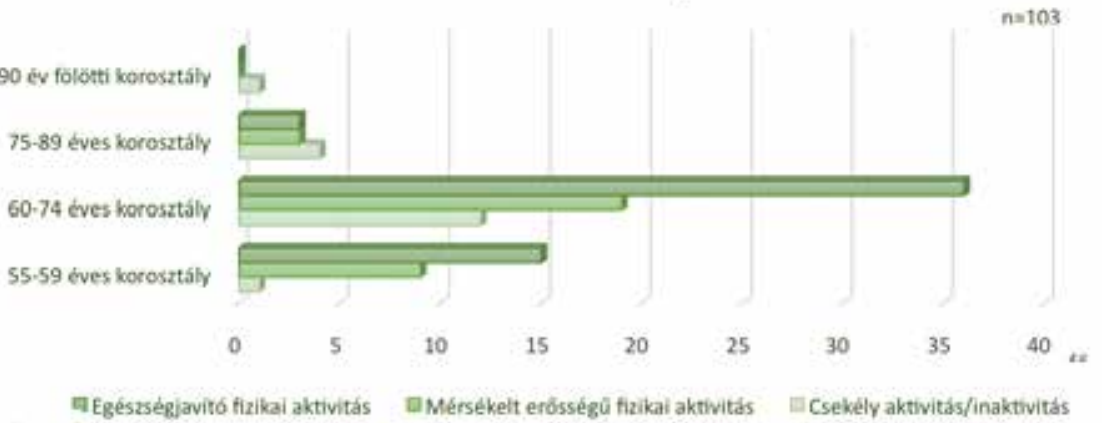

$\mathrm{Az}$ erdőlátogatás - mint az egészség megőrzésének és/ vagy az egészségi állapot javításának lehetséges eszköze vonatkozásában eredményeink szerint a minta 30,1\%-a nem szokta látogatni hazánk erdőit, hegységeit. Ezzel szembe azok, akik igénybe veszik az erdőink adta szolgáltatásokat, valahányan több lehetőséggel is élnek. Legkedveltebb időtöltésnek az erdőben történő sétálás bizonyult, a megkérdezettek közel fele $(47,63 \%)$ szívesen szenteli szabadidejét erre a rekreációs tevékenységre. A túrázási lehetőséget, mint szabadidős tevékenységet a minta 24,27\%-a választotta. Habár 
hazánkban az állami tulajdonban lévő erdőgazdasági részvénytársaságok több mint 500 kerékpárúttal rendelkeznek (Seregi és mtsai, 2014), a megkérdezett 55 év felettiek nem preferálták az erdőben történő kerékpározást (4,58\%), ahogyan a futást sem (4,58\%). Az erdő adta lehetőségek végtelenek a rekreációs szolgáltatások szektorában (Hegedüs, 2007), ezt bizonyítja kutatásunkban, hogy a válaszok között megjelent többek között a vadászat, a tájfutás, a barlangászat, a gombázás, valamint a tereplovaglás is, mint kikapcsolódási lehetőség.

Eredményeink szerint a megkérdezettek közül azok, akik valamilyen formában élnek az erdők adta lehetőségekkel, az elmúlt félévben ritkábban mentek ki, mint havonta (40,28\%), illetve havonta egyszer (30,56\%) látogatták az erdőt. Heti rendszerességgel, illetve hetente több alkalommal 22,22\%uk ment ki.

A kutatásban részt vettek nagy arányban (69,9\%) ismernek valamilyen nevezetes helyet/helyszínt az erdőkben, hegységekben. Legtöbben forrásokat, sziklákat, vízeséseket neveztek meg. Számos esetben olyan helyszín is megjelent, aminek megközelítése több órás gyaloglás útján lehetséges vagy a műútról való letérés után hosszabb időt vesz igénybe (jármüvel való megközelítése tilos) - mint a Bükkben található Andó-kút vagy a szilvásváradi Szalajka-völgy páratlan természeti szépsége, a Fátyol-vízesés.

A tanulmányban azok közül, akik egyáltalán nem veszik igénybe az erdő adta rekreációs lehetőségeket, a fizikai aktivitás tekintetében közel egyharmadukra $(32,26 \%)$ a csekély aktivitás vagy inaktivitás jellemző, és csaknem egyötödük (19,35\%) mérsékelt erősségü fizikai aktivitást mutatott.

Eredményeink szerint a csekély és mérsékelt erősségü fizikai aktivitást mutató válaszadóknak pedig a 38,78\%-a sose látogatja hazánk erdőit (2. ábra).

\section{2. ábra: Erdőlátogatási szokások a csekély/inaktív és mérsékelt erősségü fizikai aktivitást mutatók körében}

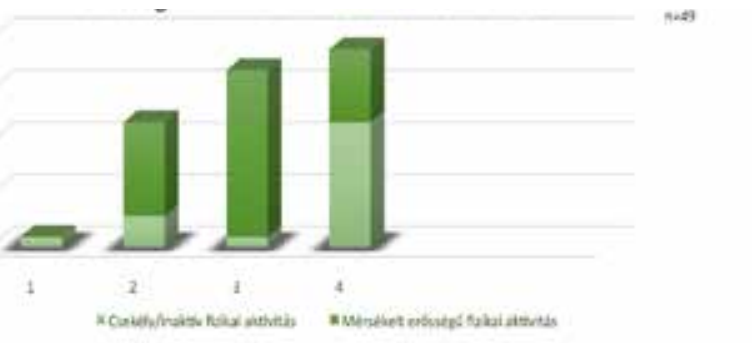

\section{ÖSSZEFOGLALÁS}

Az erdő optimális vonzerőt képvisel rekreációsgyógyászati vonatkozásban. Többségében térítésmentesen látogatható és csak ritka esetben korlátozottan ,igénybe vehető” (Seregi és mtsai, 2014) (pl.: bizonyos területeken vadászati idény alatt). Az 55 év feletti korosztály rekreációs kultúrájában mindinkább megjelenik az erdőlátogatás, ami hozzájárulhat idősödő társadalmunkban a közép- és időskorúak öregedési folyamatának lassításához. Ennek tükrében hozzá kell segíteni őket - állapotukhoz mérten - a lehető leghatékonyabb társadalmi szerepvállaláshoz azáltal, hogy az életmódjukhoz szorosan illeszkedjen a rendszeres fizikai aktivitás fogalma, amelynek hatékony módszere lehet az erdőlátogatási szokások megváltoztatása. Támogatni kell a köztudatba való beépülését az erdő adta lehetőségeknek, azok egészségre gyakorolt jótékony hatásainak. Hazánk erdőinek infrastrukturális ellátottsága lehetővé teszi, hogy a szabadba vágyó idősödő korosztály is igénybe vehesse az erdei szolgáltatások rekreációs szektorának számtalan lehetőségét (Seregi és mtsai, 2014).

\section{KÖSZÖNETNYILVÁNÍTÁS}

A tanulmányban ismertetett kutatómunka az EFOP-3.6.1-16-2016-00011 jelü „Fiatalodó és Megújuló Egyetem - Innovatív Tudásváros - a Miskolci Egyetem intelligens szakosodást szolgáló intézményi fejlesztése" projekt részeként - a Széchenyi 2020 keretében - az Európai Unió támogatásával, az Európai Szociális Alap társfinanszírozásával valósul meg.

\section{IRODALOMJEGYZÉK}

Magyar Közlöny (2009): 2009. évi XXXVII. törvény az erdőről, az erdő védelméről és az erdőgazdálkodásról. Lap- és Közlönykiadó, Budapest, 71(16): 273-302.

Ács P., Prémusz V., Melczer Cs., Bergier J., Salonna F., Junger J., Makai A. (2018): Nemek közötti különbségek vizsgálata a fizikai aktivitás vonatkozásában a V4 országok egyetemista populációjának körében. Magyar Sporttudományi Szemle, Magyar Sporttudományi Társaság, Budapest, 19(74): 3-9.

Bajsz V., Császárné G.G., Sió E. (2014): Fizikai aktivitás a kiegyensúlyozott, energikus munkavégzésért. Pécs.

Hegedűs A. (2007): A nem fa termékek és szolgáltatások hasznosítása és marketingje. PhD-értekezés. Roth Gyula Erdészeti- és Vadgazdálkodási Tudományok Doktori Iskola Sopron, NYME-EMK.

Miniszteri tájékoztató (2017): Magyarország erdőállományának fóbb adatairól a 2009. évi XXXVII. törvény 43.\$(5) bekezdése alapján. Budapest, URL: http://www.kormany.hu/download/c/ c3/41000/Miniszteri\%20t\%C3\%A1j\%C3\%A9koztat\%C3\%B3. pdf\#!DocumentBrowse (2018-07-02)

NÉBIH (2017): Országos Erdőállomány Adattár. Beszámoló az erdősítésekről és a fakitermelésekről a 2016. évben. Budapest: NÉBIH Erdészeti Igazgatóság.

Olvasztóné B.Zs., Herpainé L.J., Bognár J., Kopkáné P.J. (2011): Idős emberek életkörülményeinek és egészségmagatartásának vizsgálata. Egészségfejlesztés, 52(5-6) 24-30.

Seregi J., Lelovics Zs., Balogh L., Papp L. (2014): Az erdő egészségmegőrző szerepe. LAM, 24(1-2): 65-70.

Seregi J., Balogh L., Lelovics Zs. (2012): Az erdei mellékhaszonvétel szerepe az egészség-védelemben, a gyógyászatban és a közjólétben. Studium \& Practicum, 6(10):9-11.

Seregi J., Lelovics Zs., Balogh L. (2012): Az erdősültség hatása a születéskor várható élettartamra. Egészségügyi Gazdasági Szemle, 50(5-6): 9-12.

Seregi J. (2012): A magyar állami erdőgazdaságok közjóléti szolgáltatásai napjainkban és azok gazdasági hatása. Doktori (PhD) értekezés. Kaposvár.

Tóth I. (2017): Az időskorú betegek rehabilitációjának jellegzetességei. In.: Vekerdy-Nagy Zs. (szerk.). Bizonyítékokon alapuló rehabilitációs orvoslás. Budapest: Medicina Könyvkiadó Zrt., p: 505-515.

WHO (2001): Constitution of the World Health Organization, Geneva, 1946. Accessed Page 20 of „NATIONAL MENTAL HEALTH POLICY 2001-2005” on March 2001.

World Medical Association (2008): Ethical principles for medical research involving human subjects.

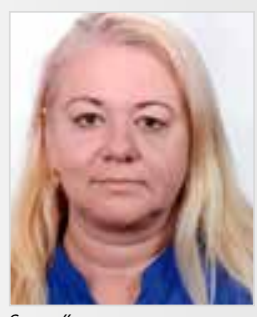

Szerző:

Dr. K. Plachy Judit

Munkahely: Miskolci

Egyetem Egészségügyi Kar

Fizioterápiás Intézeti Tanszék - adjuktus

efkplachy@uni-miskolc.hu

Érdeklődési kör: fizikai rekreációs foglalkozások

tartása minden korosztály, leginkább a nyugdíjas lakosság számára.

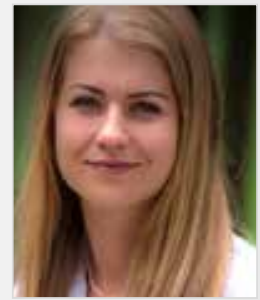

Levelező szerzők:

Perge Anna, Miskolci

Egyetem Egészségügyi Kar; efkppanni@uni-miskolc.hu

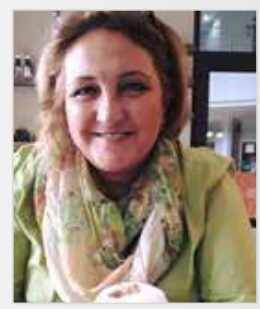

Rucska Andrea, Miskolci Egyetem Egészségügyi Kar

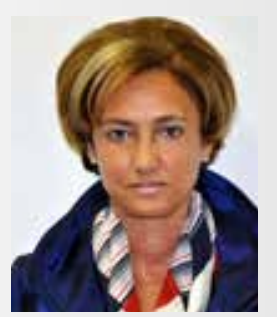

Dr. Kiss-Tóth Emőke PhD, dékán

Miskolci Egyetem

Egészségügyi Kar

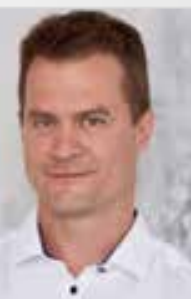

Dr. habil Fritz Péter

egyetemi docens/

Egészségtudományi vezető/ Ferencvárosi Torna Club, Miskolci Egyetem Email:pfritz@hotmail.hu. Főbb kutatási terület: sporttáplálkozás, rekreáció 